\title{
CULTURAL BORDERS IN AN AUTOBIOGRAPHICAL NARRATIVE
}

\author{
Tiiu Jaago
}

\begin{abstract}
This article examines the life story of a woman born in a village in southern Estonia in 1918. It is based on two life stories told in Estonian and one told in Russian, as well as a story about her home. The stories were written at the initiative of the researcher between 1996 and 2004 and are stored in public archives. These texts have been chosen in that they are characteristic of the multifaceted phenomenon of inter-cultural contact: the narrator is of Estonian descent; she was imprisoned during the German occupation and taken to Germany, where she lived among local Germans and Red Army soldiers after the war; she married a man of Russian descent who served in the Red Army; from 1948, she and her family lived in a culturally diverse environment in Kohtla-Järve. The focus of this research is on the manifestation of cultural borders at the levels of life history, self-description and cultural context. The narrator presents herself as a person who is not constrained by cultural borders. The relative importance of various cultures in her life and her self-perception is dependent on the general historical and political context and the context of everyday life at the stage of her life that is being described. This aspect emphasises the flexible and volatile nature of cultural borders; however, the analysis of the text reveals the permanence of cultural borders - the narrator cannot step out of her cultural background when describing a culture that she sees as 'other'.
\end{abstract}

Keywords: cultural borders, cultural diversity, life story, the Second World War, the Soviet era

...I am still confused, darting this way and that; time itself will run out before I find myself on a straight path. But am I supposed to find a straight path at all? ${ }^{1}$

In research on everyday culture, folk narrative and popular storytelling, the subject of cultural borders may be viewed from the standpoint of communities, such as an encounter with a cultural 'other' (see, for example, Greverus 1988; Wienker-Piepho \& Roth 2004). A meeting of cultures at a territorial border may raise the issue of border culture (Grenzkultur), as a mix of cultures in which it is impossible to speak of simple cultural contacts - instead, there exists a 'third space' or an intercultural area (Schmeling 2000: 349). Cultural exchange that 
is based on the culture of new settlers in a certain region may include a layer of local culture that previously existed in that region. For example, the replacement of place names in the Karelian region conquered by the Soviet Union took place in a situation where a newly imported culture 'met' a completely different tradition of place names that persisted in the region (Hakamies 2006: 33-35). Astrid Tuisk (2002) has studied how Estonian migrant community in Siberia domesticated the land they inhabited by name giving.

Similar to the aforementioned studies, this article focuses on cultural borders: encounters with the 'other', the potential blending of cultures and even the issue of exchanging one culture for another. However, I examine these phenomena from the standpoint of an individual, rather than that of a community, comparing the autobiographical narratives of a woman born in southern Estonia in 1918; three of them have been written in Estonian and one in Russian, which date back to between 1996 and 2004. ${ }^{2}$ Cultural borders are examined from three different aspects: an individual's life (the events that bring the narrator together with the cultural 'other' or other cultures), her self-description (the narrator's analysis of her position in the melting pot of different cultures), and the cultural background of the narrative (firstly, how the story in question is positioned in the context of other stories told at the same time and, secondly, how the narrator positions herself with regard to Estonian-speaking and Russianspeaking readers).

\section{THEORETICAL FRAMEWORK}

The first half of the article concerns the narrator's life history and focuses on factors that can be interpreted as relating to cultural borders. ${ }^{3}$ Since my article is based on the study of folklore (which looks less at the topic of a story and more at how the events are interpreted and what techniques are used by the narrator), it is important to consider the conditions in which the texts to be analysed were created. The texts submitted by the narrator to life writing campaign or recorded at the researcher's request are autobiographical accounts of the author's life. A story of real life is connected both to the events being described and the time when the story is told. This means that the stories are always created through an interaction with other texts and other narrators and listeners, thus it is useful to take this into account when interpreting a story (cf. Welzer 2000; Palmenfelt 2006; Laurén 2010).

Cultural borders are perceived subjectively, rather than being seen logically or unambiguously (cf. Schneider 2004). This applies to more than just the texts being analysed, since research is also affected by the factors chosen by 
the researcher as the basis for defining cultural borders. In the analysis of the life story that provides the subject of this article, the primary border marker is the use of language (Estonian or Russian - two languages that are clearly different). The narrator prefers to portray life in an Estonian-Russian mixed family through personal relationships and does not focus on cultural differences. As a researcher, I am taking the opposite approach, basing my analysis on differentiating between Estonian and Russian culture and only then examining how the narrator positions her personal relationships on the landscape of cultural differences. I have chosen to use Yuri Lotman's treatment of the semiotic (culturally significant) border as a general theoretical framework for defining the phenomenon of the cultural border:

The border of semiotic space is the most important functional and structural position, giving substance to its semiotic mechanism. The border is a bilingual mechanism, translating external communications into the internal language of the semiosphere and vice versa (Lotman 2005: 210).

Of course, since semiotic space is abstract, the cultural border may not be visually discernible. However, in cases where a cultural border coincides with a territorial border, it is manifested wherever there is need for 'translation'. Since every culture requires internal organisation, the environment outside that culture is perceived as the 'chaotic external sphere'. The border between organised (comprehensible) and unorganised (different, incomprehensible) spaces is the source of questions that make us organise the 'other' based on our culture (or, in other words, to translate the foreign culture into the 'language' of our own culture). Lotman also points out the subjective nature of the cultural borders and demonstrates that viewpoints both inside a culture and outside its borders may not coincide at all, which is why the location of the border of a specific culture depends on the observer's position (Lotman 2005: 213). In the texts I have analysed, my aim has been to look for factors in the sequence of events contained within the narrative, which could be identified as markers of social as well as ethnic and cultural borders. Events in life stories are usually reported in chronological order and this also applies to the narratives analysed in this article. Causality also plays a role in the event structure of a story, in addition to temporality (Grišakova 2010). I attempt to understand how the narrator interprets the events of her life story from the standpoint of the narrative as a whole and how she justifies the selection of events she has chosen to include in her autobiography. In advance it can be said that from this standpoint, the cultural background of the narrator proved to be important (including, for example, her relationship with literature and music).

The second part of the article focuses on the cultural background of the narratives (for instance, I examine how the story told in Estonian differs from that 
told in Russian, aside from the fact that they use different languages). In her study on experiential narratives, Kirsi Laurén emphasises the fact that along with describing real life events, narratives also reveal the cultural background in which the narrators of the stories have grown and that have shaped their identities (Laurén 2010: 426). This is also true in the case of the narratives analysed in this article: the narrator may have an excellent command of both languages and the events on which the narrative is based, and the life experience connected to the events may be the same, but it is still impossible for the narrator to use the same storytelling techniques in Estonian and Russian. For example, she cannot explain much to her Russian-speaking audience through Estonian poetry, although she uses such quotes in an expressive manner within her Estonian text. The opposite is also true: she is not familiar enough with Russian poetry to address her audience through it, not to mention using it to interpret her life experience. Therefore, regardless of her language skills, she cannot find an equal (or analogous) common cultural element with her Estonian and Russian readers.

\section{CULTURAL BORDERS IN THE LIFE STORY}

The narrator was born on November 8, 1918, in a southern Estonian village where her parents had a farm. 1918 was a pivotal time in Estonian history. The Russian Empire had ceased to exist although the Imperial era still persisted in the stories of the narrator's ancestors and grandparents. The First World War ended three days after she was born. Her parents and grandparents had lived through this war. Her father was 'under the gun' (her own words regarding her father's participation in the war) and later told his children about his life as a soldier and sang songs he had learned during the war. The War of Independence for Estonia's national sovereignty began on November 28, 1918, and lasted until January 3, 1920 (Estonia declared its independence on February 24, 1918).

She spent her childhood and youth in the independent Republic of Estonia where fundamental political change was a thing of the past and people concentrated on coping with their daily lives. In her story, this fact is reflected in the descriptions of the daily chores of a family living on a farm and a lifestyle characteristic of Estonian society at the time: she describes how the children tended to the herd, and the skills she had to learn in order to cope with farm life as an adult. She also talks about her grandmother's interesting stories and folk wisdom as well as the family's passion for music and a Christian way of life.

In 1937, she married a schoolteacher. This changed the narrator's life not only in the personal sense, but also socially. She was no longer a member of a 
farmer's family - she had become a representative of the urbanising culture. Instead of farm work, her life was now dominated by issues of education and temperance. Since her husband was a communist, the course of her life after the incorporation of Estonia into the Soviet Union in 1940 began to be shaped by the changes in the status of Soviet power within Estonia. For instance, her stories put an emphasis on the beginning and end of the war between the Soviet Union and Nazi Germany (June 22, 1941, and May 9, 1945). After the start of the war, her communist husband was shot by the German occupation forces. For her, the end of the war meant being freed from a German prison camp. According to Aigi Rahi-Tamm (2005: 42) approximately 4,000 people from Estonia were sent to prison camps during the German occupation. The narrator was one of those prisoners, having been arrested in the winter of 1943 for associating with people who supported the Soviet regime. She was first imprisoned in Tartu and then Tallinn. When the front was moving westward, she was taken to the Stutthof camp in Poland late in the summer of 1944. However, her stories never devote much attention to the Soviet mass deportations carried out on June 14, 1941, and March 25, 1949, when nearly 30,000 people were sent to concentration camps or forced exile in the eastern regions of the Soviet Union (Rahi-Tamm 2005: 25, 29, 41). Unlike the narrative in question, most life stories told to the public during the same period (the 1990s) emphasise the issue of Soviet repression (Hinrikus \& Kõresaar 2004: 24; Kõresaar 2004: 54-56).

As a former prisoner, she was unable to immediately return to Estonia after the end of the war in May 1945, so she stayed in the Soviet zone in Germany, living among local Germans and the Red Army soldiers who had won the war. A year later she married a man of Russian descent, who served in the Red Army. They were initially hoping to settle in Russia, but her husband found work in Kohtla-Järve, a rapidly developing industrial town in north-eastern Estonia, which was sovietised very quickly after the war. ${ }^{4}$ The narrator has lived in Kohtla-Järve since 1948.

In her descriptions of life during the Soviet era, she focuses on describing her family life rather than the social situation:

I had an interesting life. There were so many new experiences. I was free to immerse myself in the routine of my daily home life for long periods of time because I knew that [my husband] would always think of something new and interesting. ${ }^{5}$

For her, this was a safe time together with her family as opposed to during the war. Her understanding of the Soviet regime was altered by the facts she learned about other people's fates, rather than her own experience. She says that her change of mind occurred in 1953, after Stalin's death, when people 
who had been deported to Siberia began to return to Estonia. She was able to relate to the experiences these people had had while imprisoned:

[---] her tragic experiences in the Siberian taiga led me to seek parallels with what I had experienced in the camps in Germany. There was some terrible similarity between the two. I was much older by then. I had to admit that my naive belief in Russian communism had waned. ${ }^{6}$

Due to the fact that the narrator's prison experience was publicly recognised during the Soviet period, she was invited to talk in schools and she participated in the work of an association of former prisoners through which, in 1968, she was able to visit the former Stutthof prison which had been turned into a museum. The people repressed by the Soviet authorities were only able to publicly talk about their experiences at the end of the 1980s (see Jaago 2004b: 179-181; Kõresaar 2005: 17-20). Over time, she grew to understand lives that were different due to political reasons from a standpoint that was not based on the concepts of right and wrong: "My goodness, I hadn't heard anything about Gulags back then." - "Now I think myself how difficult it must have been for the huge number of Gulag victims to be silent... I don't even know when information about this began to leak through."

Her stories portray the early 1990s (the first years after the restoration of Estonia's independence) as a rather grim period: the economic reorganisation and the establishment of private companies led to a situation in which bars had to be installed on the windows of homes to protect them from intruders, and murder and fraud became an everyday phenomenon. She tries to distance herself from the changing social situation and focus time and again on her family. ${ }^{9}$ In the texts stored in the Estonian Life Histories collection and written in the second half of the 1990s and the beginning of the 2000s, autobiographical events are predominantly placed in the context of the liberation of Estonia from foreign rule (cf., e.g., Kõresaar 2005: 17-35). She, however, does not describe her attitude towards the restitution of independence in Estonia. Her writing is based on her personal everyday experiences at the beginning of the 1990s, and she refers to this period with the comment: "what an awful time to live in". This is partly due to her living environment - Kohtla-Järve had been established as and had developed into a Soviet town. Compared to people living elsewhere in Estonia, the collapse of the system was more difficult for the people of KohtlaJärve, both economically and mentally. There were many who lost both their livelihoods and their homes, and the culturally diverse town also had to adjust to the change in mutual relations between ethnic groups in Estonian society (cf. Jaago et al. 2008: 290-295; Jaago 2011). However, her opinion of the beginning of the 1990s is also influenced by the fact that one of her sons died as a result 
of events related to the world of complicated disorganised laws and business relations, which was characteristic of the period in question.

Therefore, the political framework of her course of life is as follows: war (1918-1920), peacetime (1920-1941), war and imprisonment (1941-1945), a new period of peace which is also the Soviet era (1945-1991), the first years after the restoration of independence to the Republic of Estonia (the 1990s). It is clear that her individual timeline intersected with the political and historical timeline and this is how she sees it: "I am a child of my times, and I got caught in the cogwheels of history". ${ }^{10}$ Despite being "caught in the cogwheels", she is not a passive individual. Her active nature becomes apparent when we analyse the cultural levels of her narratives. For example, it is noteworthy that she conceptualises her life through poetry. The end of the story she wrote in 1996 is a straightforward example of this ${ }^{11}$ and she wrote the story while mourning for her son who had died a year and a half earlier. This mourning brings up the question of the meaning of life and she quotes the Estonian poetess Anna Haava:

Is this what life is?

A fleeting, restless dream,

a string of struggles, tribulations, losses [---].

"No," she declares, and the opinion coincides with the words of Virve Osila, another poetess:

In life you must know how to

wish for miracles

feel all the joy and bear all the burdens [---]. ${ }^{12}$

Time and again, she lingers on the symbolic borders in her life. Her readiness for crossing boundaries is exceptional. For example, although she was a child from a family of farmers, she wanted to and did escape that social class. Due to the fact that her mother had grown up in the city, they had a lot of things in their home that other people in the village did not. In her Russian-language story, the narrator says that during the time she lived in the village, she always wanted to stand out from the rest, although she could not say why. She also states that she liked her new life as a schoolteacher's wife, which provided her with access to new living conditions, new hobbies (such as learning Esperanto), and different people. Considering these facts, it is not at all surprising that after the war she was ready to start a new family with a representative of the Russian culture, which was significantly different from Estonian culture.

The perception of borders also has an effect on her descriptions of herself:

There are two opposites living inside me. Perhaps this is because I am a Scorpio ${ }^{13}$ and the sign is associated with both earth and water? Or 
perhaps the two opposites are Adam and Eve? Who knows, perhaps I am carrying on the tradition of the characters and industrious workers of burgher stock on my mother's side of the family? I have definitely inherited a solid dose of the salt-of-the-earth cheerful dreamer nature from my father's side.

Therefore, her 84 years on this earth have simultaneously felt "as if she was taking part in a horse race" as well as being "a dreamer at the window". ${ }^{14}$ She discusses the reasons underlying her desire to differ from 'others' and the question of whether she really has to be either 'here' or 'there'.

\section{THE ARCHIVAL CONTEXT OF THE STORIES}

The texts analysed in this article have been taken from the collection Estonian Life Histories, which was created in 1989 (i.e., at the end of the Soviet era) on the initiative of the employees of the Estonian Literary Museum and by researchers of life stories. On the one hand, the development of this collection has been based on the century-long tradition of collecting folklore and cultural historical material in Estonia, where calls for contributions are published in newspapers and voluntary contributors send in their texts. On the other hand, the mid-1990s saw an increase in cooperation with Finnish sociologists and life story researchers (Hinrikus 2003: 178-181). Collection campaigns were held and they generally had a specific theme (e.g. My destiny and the destiny of those close to me in the labyrinths of history (1996), Teacher, do you remember your life story? (1997), One hundred lives of a century (1999), Life for me and my loved ones amid a changing environment (2000), etc.). This method of collecting material is relatively similar to the collection campaign tradition in Finland (cf. Pöysä 2006; Laurén 2010). The instructions for writing life stories, which are published in all Estonia's major daily newspapers, specify that the narrator should talk about his or her life and cover the entire life history. At the same time, the narrators are not expected to focus on specific sub-topics and they are not asked questions that would encourage them to elaborate, for example, on a historical event or a situation in their personal lives. The resulting contributions are written narratives of various length and structure. The collection currently contains approximately 2,500 written autobiographical accounts and several anthologies have been published on the basis of the collected material. ${ }^{15}$

The narrator whose texts are analysed in this article has submitted three life stories to the Estonian Life Histories collection. The motive for writing the first life story submitted in 1996 was the call made by the Estonian Life Stories Association and the Estonian Cultural History Archives for contributions related 
to the topic My destiny and the destiny of those close to me in the labyrinths of history. ${ }^{16}$ One year later, she submitted to the archives an updated version of the same life story: while the biographical episodes mostly overlap with the earlier narrative, the author has added passages of poetry and has a different way of addressing the reader. ${ }^{17}$ In 2004, she also submitted her story in Russian at the request of those in charge of compiling an anthology of Russian-language life stories..$^{18} \mathrm{I}$ have also been able to use the materials I recorded during meetings with the author on December 11, 2002, and June 3, 2005, as well as her story about her home and family, which she wrote at my request in $2002 .{ }^{19}$

It is important to note that all four stories have been written after the end of the Soviet era, since Estonia regained its independence. The discursive background of the life stories written during the second half of the 1990s and stored in the Estonian Life Histories collection, was shaped by a shared focus on Estonia and the tendency to discuss topics suppressed by Soviet history, such as the political repressions carried out by the Soviet regime (see, for example, Kirss et al. 2004; cf. Kõresaar 2005: 12-14, 20-26). As already mentioned briefly above, the contribution analysed in this article is somewhat different. She discussed the crossing of cultural borders under the Soviet regime on an individual level (which, if we consider other life stories, was not the norm at all) and her experience of a German prison camp (which was a subject that had previously been publicly discussed during the Soviet era, unlike the issue of Soviet prison camps). Also, she does not equate the restoration of the independence of the Republic of Estonia with the restoration of Estonia's natural course of development after the interruption of the Soviet era; instead, she considers this period to be a "terrible time for living" and describes the hardships of the transition era as they appeared in her everyday life. In terms of depicting life in Estonia before the Second World War, her story is generally similar to others: the period is portrayed as a peaceful and safe time spent among a harmonious and functional farming family (see, for example, Kirss et al. 2004; Kõresaar 2004: 54-56; Kõresaar 2005: 37-110).

The general and expected catalysts for the events in narrators' lives in the written life stories of the second half of the 1990s were historical and political events. This also applies in the present case, although this narrator's stories belong among those narratives that stand out from the rest by way of their distinctive characteristics. It is conspicuous that she does not interpret the past through schemes that have become familiar to us through common discussions. For example, she does not idealise farm and village life to such an extent that it could, in terms of the story as a whole, become "a metaphor for the nation state" (see Kõresaar 2005: 41 concerning the concept and its treatment), nor does she describe her post-imprisonment reunion with her daughter, who was 
left behind in Estonia, as a problem-free process: they were separated for five years and she did not recognise her daughter when they were reunited. Generally, the painful nature of such family reunions after the narrator's return from prison or exile (which, as a rule, meant that the people had been apart for six or seven years, and maybe more than a decade) was not admitted as publicly during the $1990 \mathrm{s.}^{20}$

Instead of representing a value system, the narrator of the texts subjected to analysis tends to use her life story to discuss the contradictions in life. On the one hand, she claims not to have been interested in politics, but on the other hand, politics is the factor that has the most direct influence on her personal life. In her narratives, she is more or less ready to depart from her familiar environment and is able to adapt what is already there, to the new. However, this is often accompanied by a conflict between her ideals and the reality of life. For instance, when she describes falling in love with the schoolteacher who played the violin, she forms an association between this event and her fondness for reading as a young woman: "The books used to take me away to distant lands and I could look forward to dreams of happiness and love." In this episode, she mentions a book that inspired her to imagine the prince of her dreams. ${ }^{21} \mathrm{How}$ ever, as a by-product of falling in love, she experiences a discrepancy between her ideal husband and reality. She describes her shock when she learned that the man she loved was a communist: for her, a communist was a person planning to overthrow the government, a negative character who stood in contrast to the feelings of safety that she had felt at home and at school. Despite this, the political reality and the negative image of communists do not prevent her from deciding that her beloved is a good person. The selection and order of the events in the life story indicate that the narrator does not call into question the choices she has made in her life. By telling her story in such a way during the $1990 \mathrm{~s}$, she ran a certain risk of having her choices interpreted through the prism of political convictions. Therefore, the reader may have decided that since the narrator joined the side of communists and representatives of the Soviet regime, she consequently did not hold Estonian culture and Estonia's national independence in high regard. In other words - her stories required the reader to be tolerant.

Her narratives are structured so that the communication of the sequence of events is frequently interrupted. She speaks with the reader and interweaves her story with poems from well-known authors, song verses and words of wisdom she has heard from others and carries with her as "important ideas about life". Her texts are handwritten (she does not use a computer or typewriter). She uses different colours and pastes photographs or clippings from other texts in between her own text. The letters I have received from her also contain a 
varying number of quotes from Estonian poets, which she links to her message. When in December 2002 she gave me her story about her homes (which I had asked her to write), she apologised for having used poetry in the story. She started off that story with a quote borrowed from Betti Alver, one of Estonia's most famous poets, which spoke of the contradictory nature of our souls. ${ }^{22} \mathrm{I}$ asked her why she used poetry in her texts. She explained:

I am not sure; it's just how I feel. It might be because I used to keep a diary. And in this diary, I would write at the beginning of each day... everything started with a poem... it was like a motto. [---] The poem gives your thoughts a direction. You might not know where to begin but the poem puts your thoughts on the right path. ${ }^{23}$

In connection with the habit of keeping a diary as a young woman, the narrator also showed me the current writing tradition practiced by her family: important anniversaries of their family members are celebrated by designing handwritten books that contain good wishes from the other members of the family. The books consist of short texts written especially for the occasion (memories, descriptions of episodes in the person's life, etc.), as well as verses traditionally used in albums or borrowed from songs, poems, and clippings from photographs, postcards or magazines. The collage technique described above is also used in the life stories the narrator has sent to the Literary Museum, although to a somewhat lesser degree. As such, it appears that the narration of the stories the author has submitted to the archives is often grounded in the narrator's earlier and parallel experience of storytelling or writing. ${ }^{24}$

\section{THE THREE CULTURES IN THE NARRATOR'S LIFE}

Above, I have discussed the narrator's readiness to cross the boundaries of an environment that is familiar to her. This is also true in the case of crossing ethno-cultural borders. As expected, the narrator presents (and probably also experiences) her life as a whole, rather than as a process of wandering within and between different cultural spaces. In the following section, I attempt to demonstrate that in the narrator's life these different spaces do not exist simultaneously or as a culturally uniform (merged) entity. Instead, they are experienced as separate spaces which the narrator can enter or distance herself from during different stages in her life, in different situations and when performing different roles. She portrays her movement in the common ground shared by the cultures from behind the cover of personal relationships. When she notices the merging of cultures within herself in the course of the process, she describes it as a temporary phenomenon and claims that she can shake it off. 
Her post-war life in the Soviet occupation zone in Germany raises the issue of the boundaries between ethnicities (Estonians, Russians, Germans), as well as the division of power between the representatives of the different ethnic groups (as winners of the war, Russians also represented power). The convergence of the political and ethnic background in her personal life is marked by her marriage to a Russian Red Army officer in the summer of 1946. Just as in the case of her first husband, she avoids linking her decision to marry to choosing any ethnic or cultural 'side' and instead keeps moving in the border area between cultures without positioning herself clearly. To her, this is the obvious thing to do and she is able to do this because her choices are always based on personal relationships between people and she eschews general stereotypes and attitudes. A sense of the dominant and ever-present political power can be felt in the background of the narrative. This becomes apparent, for example, in her description of how her husband (a representative of the Soviet regime in Germany) helped the local Germans by finding work for them. Her own ethnic and cultural situation was rather peculiar during the period of her life she spent in Germany. For example, to the prison guards she was a Russian (Russische Schweine) because she came from Eastern Europe. A separate hierarchy of ethnic groups existed among the prisoners themselves and Estonians seem to have been positioned on the lower end of the spectrum, although she does not provide a very detailed description of this phenomenon. ${ }^{25}$ When she accompanied her Russian husband to a party for the Red Army soldiers, the people with a Russian cultural background considered her style of dress to be Western European and her husband's friends' attitude towards her proved to be problematic. We can ask whether the event described in the life story is the context of the party or the experience of a different culture that made the narrator think about cultural differences reflexively. The latter would probably be the correct answer. The narrator provides a more explicit description of the connections between ethnicity and the division of power in her account of how she had a nanny in Berlin after the war. The narrator's neighbour, a German woman, was her nanny. On the one hand, members of the Russian community used to ask the narrator how she dared to leave her child in the care of a German person, while the nanny had to face rhetorical questions about how she could love the child of a Russian person. ${ }^{26}$

It is interesting to note that although the narrator socialised with her German neighbours, her story contains no descriptions of the everyday life of a German family. That is not true for Russian families, however. The narrator makes note of and describes the cultural differences she experienced when her husband took his wife and child to meet his mother. For example, she provides colourful descriptions of the Russian stove, the samovar, the religious icons 
and her mother-in-law's tea drinking tradition and piety. Her comparison of the three cultural environments is summarised in the following observation:

I felt that this home [of her husband's relatives in Russia] was governed by semi-patriarchal customs and was very different from anything I had encountered in Germany and even more so from my childhood home in the country. ${ }^{27}$

Also, the narrator's descriptions of post-war Germany make no mention of the maintenance of the city. Her memories of the first time she saw Moscow on May 2, 1948, however, are dominated by her dismay at seeing the streets filled with litter. Her attitude towards the maintenance of public order as an issue related to a clash of cultures is also briefly mentioned in connection with Kohtla-Järve in Estonia. She says that many of the Russians arriving in the town had served time in prison and used terrible language:

Estonia became more alien to me. There were husks of sunflower seeds strewn about everywhere. The two cultures, mostly represented by uncultured individuals, would clash ever more violently and send sparks flying. One side thought that this was their land now and the other thought that it was their homeland.

The narrator's opinion was that "there should be order. Cleanliness". ${ }^{28}$ Unlike her account of post-war Germany, her stories of the visits she has made to Germany in the recent past do mention the environment. She admires "the wonderful towns on the slopes of valleys [---] adorned by the abundance of flowers in May" where they "saw neither criminals nor policemen during our two-week trip". ${ }^{29}$ These surroundings are contrasted with her own home during the same period: the one-room apartment in a concrete block house in KohtlaJärve, which she protects with "two locks as well as a chain at night and a peephole, due to the fact that my new six-month-old TV set, radio and other appliances disappeared without a trace a year and a half ago and are being used by someone else," she says, referring to a break-in. ${ }^{30}$ The manner in which she portrays 'the other' in comparison to her own home environment also reveals her feelings about her home at the time. If post-war Germany seemed familiar to her and similar to the environment she had known at home, she does not write about it. If Germany at the end of the 20th century stood in contrast to the post-Soviet environment of Kohtla-Järve, then on that level, the cultural environment of Germany was more familiar to her than that of Kohtla-Järve in the 1990 s and 2000 s.

The narrator proves that the cultures she was exposed to were mingling within her, by stating (in regard to her return to Estonia in 1948): "[---] a lot of 
strange things stuck with me as a result of living in that jumble of Russians and Germans [in post-war Germany]". ${ }^{31}$ She also discovered that she had started talking in a mixture of Estonian, Russian and German. Although this shocked her relatives in Estonia, it was a temporary phase. Language problems within her multi-ethnic family presented themselves in the long term, however. For instance, her daughter from her first marriage did not speak any Russian, which is why she could not communicate with her stepfather for many years: "it was several years before they could speak to each other" (but in which language?); the daughter born in Germany from her second marriage could speak Estonian and would reply to her Russian father in Estonian. ${ }^{32}$

All three children born from her second marriage have Russian names. In the case of one name, she says that she was unsure about her husband's choice, while in the case of another name she remembers having suggested it herself. Maybe these examples do not point to some ethnic and cultural orientation on the part of the narrator but alternatively, perhaps the lack thereof? She recognises the contrasts that exist within her family due to their different ethnic origins. For example, she and her husband used to participate in both Estonian and Russian cultural events, but only due to each other's influence, not because they personally wanted to. Also, the narrator states that her husband's gift to her for the birth of their son was made "according to Russian custom". She also mentions that he never made it back to Russia, since his grave is in Estonia. However, she does not consider these ethnic borders within her family as sources of conflict. She demonstrates that she and her husband made an effort to solve the problems stemming from their different backgrounds (choosing the names for their children, deciding how to spend their free time, etc.) to please one another.

In the case of the family, we see that the process of cultural reception occurs simultaneously and that occasionally choices have to be made (e.g. the choice of Russian names for the children or the fact that the Russian husband was buried in an Estonian cemetery), whilst at other times the parties remain neutral participants who simply note the differences (e.g. when they receive "a gift made according to Russian custom"). The relationships outside the family also seem to function, with the family tending to inhabit one cultural space at a time. In these cases, the presence of different cultures in the narrator's life may be seen as consecutive, rather than simultaneous (i.e., the cultures do exist side by side but are practiced separately, one by one). For example, the narrator describes spending summers with her children in her childhood home in the midst of her Estonian relatives in a southern Estonian village. When the family lived in Kohtla-Järve, they used to communicate more with Russians who were her husband's colleagues during the first few years (the end of the 1940s and 
the first half of the 1950s). The narrator mentions, however, that eventually she felt an increasing need to experience the Estonian cultural context.

Therefore, the mutual connections between the cultural spaces in her life cannot be viewed from one dimension alone. As a result of personal relationships, different cultures may coexist more intensely in her private life but as the effect of personal relationships declines, so does the presence of the 'other' culture. At the same time, she is able to switch between cultural spaces during the same stage in her life: for example, she lives in the Estonian environment while spending summers in the country with her children and experiences the Russian environment in the winter when she communicates with her husband's circle of friends in Kohtla-Järve. Her description of either happening to enter or willingly entering the 'other' culture reveals how different she feels it is from her 'own' culture.

\section{CULTURAL CONTEXT OF THE STORIES}

Naturally, all of the texts tell the same life history; however, there are differences in how the narrator positions herself in relation to her imaginary audience. She opens her first story, written in 1996, with this statement:

I do not know how life stories are written. My readers, I do not know who you are. I will lend you my eyes and my heart so that you might see and feel along with me. ${ }^{33}$

The story she wrote a year later begins with the following passage, however:

I realise that the question may emerge, how I could condense the 78 years of my life into writing so that some more diligent readers might be able to finish the story. Why not? I have a stack of unbound empty sheets of paper on my desk. That's how I'll begin. The unbound pages of my life story.

To live one's life to the end.

To be close to someone.

To be needed by someone.

To do a bit more good than harm.

Sometimes to be peaceful and happy. (Katre Ligi). ${ }^{34}$

While the first story is a coherent narrative that is not divided into subchapters, the second story is structured chronologically and thematically: the events are presented in the order that they occurred in real life, but the topics that the narrator discusses are expanded upon through recollecting and discussing similar events. She begins each new topic with a quote (a poem, a piece of folk wisdom, 
etc.). If we take into account the time when the poems were published, we see that many of the collections of poems she quotes were published in the mid-1980s or during the second half of the decade. Clearly, this is another indication of the narrator's love of reading and its connection to her self-searching in the 1980s.

The life story written in Russian is composed as a story being told to the narrator's grandchild, a Russian woman, and becomes a kind of a dialogue between the two. She pastes clippings from her granddaughter's letters in between her own handwritten text in order to direct the flow and tenor of the story. Therefore, the narrator's use of the excerpts from her granddaughter's letters is analogous to her use of quotes from poems in the story she tells in Estonian. For instance, the story contains an excerpt from a letter sent to the narrator by her son's daughter who lives in Italy and reminisces about visiting her grandmother's childhood home. She writes that it was the most beautiful place in the world. The grandmother continues from here. She says that when she lived on the farm as a child, she wanted to soar like a bird and see what was hidden beyond the horizon. This way of presenting the past seems philosophical, to a certain extent. It displays the different points of departure of two young people: on the one hand, a young woman who is travelling the world looks back from Italy to the yard of her grandmother's childhood home, while on the other hand, the narrator recalls the days when she was young and wanted to see the world and escape the confines of her family's farm. This contrast is only imaginary, however, since the narrator is also familiar with the world that lies past the horizon she saw from her home. It seems that she has chosen this method for telling her story in order to find (or create) some experiences in her life that her readers could share. The effort to find this common element is supported by the collage technique, which makes the narrator's style so distinctive. She is not a narrator who would simply tell her life story.

The broader context of the stories the narrator tells in Estonian has its basis in cultural history: her descriptions of people's lives and daily existence paint a picture of the history of Estonian society and yet this clashes with political history. She talks about her ancestors' lives in Imperial Russia and the conflicts between the peasants and their landlords; she also tells her readers about school life in the Republic of Estonia, the organised activities related thereto and the cultivation of patriotism in the 1920s and 1930s. Her life story in Russian, on the other hand, focuses on personal relationships and avoids discussing the cultural background, which would likely be incomprehensible for someone who has not studied in an Estonian school or read Estonian literature. However, if we look at the situation from another perspective, it becomes apparent that she is unable to provide a background of cultural history in her Russian-language story due to the fact that she is not as familiar with Russian culture as she is 
with Estonian or perhaps even German culture. Russian culture reaches her in a fragmentary manner and she describes the phenomena originating from it as being done "according to Russian custom" or in some other manner that emphasises their difference and the fact that they lie beyond her own cultural border. In the story she tells in Estonian, the narrator describes the children of her grandchildren and says that she is teaching them songs that have been well known to Estonians for several generations. As a reader, I recognise the songs from the titles she mentions (Õrn punased purjed [Red sails], Kungla rahvas [People of Kungla]), meaning that I know the words and melodies to these songs, I have heard them myself and I am able to place them according to periods and performers. ${ }^{35}$ We come from the same culture. The narrator does not display such cultural connections in the story she tells in Russian. Although she says that her family used to enjoy singing, she does not mention which songs were sung. She says only that her mother sang "her city songs" (her mother had been born and raised in the town of Tartu), while her father sang "his war songs" (her father fought in the First World War). She refers to the different styles but not to the songs themselves, since the narrator does not share the common cultural element of the songs with her granddaughter. This is also true for her and the broader public to whom the story is actually addressed and who is, in this respect, in the same situation as her grandchild.

\section{SUMMARY}

The narrator describes contacts between different cultures based on her role at each stage of her life: she was a farmer's daughter and became the wife of a schoolteacher; after that, she was a political prisoner and became the wife of an officer in the army that had won the war and also belonged to another ethnic group; she was a member of an Estonian family and became a member of an ethnically mixed family. In describing the encounters between cultures, the narrator emphasises the role of personal relationships rather than her own cultural orientation. For example, her relationship with her husband who belongs to another ethnic group is based on love and a shared daily routine. She does not suggest that her communication with her husband brought about a merger of cultures. She demonstrates that cultural choices in her marriage were reduced to taking each other's feelings into consideration. Her relationships with her children and grandchildren are more complicated. Although she does not analyse those relationships as much as she does the one between her and her husband, she does point out that while the family of her daughter, whose life was grounded in Estonian culture, retained their connection to Estonia, 
her sons' children, whose mothers were not Estonians, have moved to Western Europe. She sings "beloved songs from long ago" to her daughter's children and writes down her life story in Russian for the others.

When describing cultural differences, the narrator prefers to observe rather than judge. Even in the cases where she has to assume a cultural position in conflict situations, she does so by way of describing what she felt and avoids condemning 'the other'. This approach is in keeping with her general selfdescription: she continues to be prepared to cross cultural borders and stand out from others like her.

Cultural borders are expressed in the narrations through other factors. The division of political power between the cultures that come into contact with each other is one example of the occurrence of such factors that are, however, mainly related to the functioning of personal relationships in culturally diverse circumstances. The narrator's choice to base the telling of her life story on the personal level begs the question of how she interprets the connection between the co-existence of different cultures and political power. It is clear that in post-war Germany as well as in Soviet Estonia, different cultures made up a hierarchy. She makes note of this fact (the position of Estonian and Latvian prisoners when compared to prisoners of other nationalities; the relationships between her Russian husband and the local Germans; the choice of the language of communication and future expectations in an ethnically mixed family) but avoids discussing it further. One reason for such an approach may be the fact that she has experienced many cultural hierarchies during her life and they have proved to be changeable. Therefore, she does not focus on her own cultural preferences and generally tries to efface the issue of cultural hierarchies in her story. It seems that she even considers such hierarchies to be incidental, when compared to everyday humaneness, which is timeless. The other reason is related to her personality: she demonstrates the contrast between her ideals and real life. Quite a few of her ideals and several events in her life bring her into a position of power in the circumstances of cultural diversity (for example, her marriage to a Russian man makes her one of the winners of the war in Germany and a representative of the Soviet regime in Soviet Estonia). At the same time, in these situations, her own cultural background was 'other' in relation to the 'culture of power'. The situation had been reversed by the time she told her stories in the 1990s and 2000s, after Estonia had restored its independence, and in terms of her background, she belonged to the 'culture of power' although she had relinquished her position to some extent through the decisions she had made in life.

On the basis of the stories analysed here, the cultural borders and different cultural spaces identified within can be differentiated on three levels. First of 
all, it appears that different cultural spaces existed side by side in the narrator's life and she practiced them consecutively rather than simultaneously. Let us consider, for example, her family life in a culturally diverse town compared to the summers she spent in her childhood home in an Estonian village; the gettogethers they had at home with her husband's Russian colleagues compared to her increasing need for an Estonian environment and spending time with Estonians, and the fact that she and her husband used to alternate between visiting Russian and Estonian cultural events. Secondly, her life among alien cultures in post-war Germany where she had no contact with Estonians led her to believe that cultures were blending within her. She experiences this as a detachment from herself: "am I the same person as before?"; "a lot of strange things stuck with me". In retrospect, this period was episodic in character due to the inflow of new situations and experiences. Thirdly, the comparison of Estonian and Russian texts revealed that different cultural backgrounds establish limitations for the narrator as well as the recipients of the story. Neither the narrator nor her audience can escape their cultural backgrounds in interpreting the life events and understanding the story, although the events that occurred in the narrator's life can be communicated in a similar fashion in both languages.

It follows that the presence of different cultural spaces in the narrator's life did not bring about a mingling of cultures - instead, the differences between the cultures are expressed through each other and in relation to each other. At certain points in her life, the narrator is able to move between cultural spaces. As a result of this process, comparable common elements can be found in different cultures (e.g. the issue of cleanliness in the narrator's comparison of her home and German culture). The immateriality and flexibility of cultural borders becomes apparent on this level of the life story. On the level where events are interpreted (which, according to Lotman, is a semiotic space), both the narrator and the reader have a need for their own specific cultural contexts. Cultural borders are much more rigid here than they are in regard to descriptions of life events. When she tells her story in Russian, the narrator is unable to use the same cultural texts and cannot rely on Estonian history as she does when telling the story in Estonian. This endeavour is rendered impossible by the lack of common cultural knowledge between the cultural space of Estonians and the cultural space of the Russian-speaking population of Estonia. This divergence of cultural backgrounds is not only apparent in the case of the two communities, but also within the narrator's own family, and so demonstrates that she is in fact unable to escape her own cultural background when describing a culture that she sees as 'other'. 


\section{ACKNOWLEDGEMENTS}

This research was supported by the project Writing Cultures and Traditions at Borders (SA131578) and the European Union through the European Regional Development Fund (Centre of Excellence CECT).

The narrator's quotes have been adapted from the translation made by Tiina Ann Kirss (Kirss et al. 2004: 144-165, 298-317).

\section{NOTES}

1 Letter sent by the narrator of the life story to the author: MK: Ida-Viru County, letter by M. T., 7-8 June 2003.

2 The three texts are stored in the Estonian Cultural History Archives of the Estonian Literary Museum: the collection Estonian Life Histories - EKLA f 350, 405: 1 (1996, 61 pp.), 405: 2 (1997, 78 pp.) and EKLA f 350v, 57 (2004, 69 pp.). One written account (Võorras ja oma kodu ja lähiümbruses [The foreign and one's own in the home and its surroundings], 2002, $26 \mathrm{pp}$.), the narrator's letters to the author and the fieldwork materials related to the meetings are stored at the Department of Estonian and Comparative Folklore of the University of Tartu, MK: Ida-Viru County, M. T.

3 I have previously analysed the Estonian autobiographical texts of the same narrator (Jaago 2004a). At that time, my analysis focused on her story in the context of conflicting historical events and migration.

4 Kohtla-Järve became a town in 1946, after being established on the site of old villages and mining settlements. Among others, the inhabitants of Järve village had to remove their farmhouses and their village was replaced by a new town district built according to plans ordered from Leningrad (St. Petersburg). The population of the town was largely made up of immigrants who came to Estonia from the eastern parts of the Soviet Union. According to the 1959 census, for example, Estonians made up less than $40 \%$ of the population and this level had dropped to $23.1 \%$ by 1989 (see Valge 2006: 41-42, 59-60; Jaago 2004a).

5 MK: Ida-Viru County, M. T. Võõras ja oma kodu ja lähiümbruses, 2002, p. 11.

${ }^{6}$ MK: Ida-Viru County, M. T. Võõras ja oma kodu ja lähiümbruses, 2002, p. 14.

7 EKLA f 350, 405: 1 (1996), p. 32.

8 EKLA f 350, 405: 2 (1997), p. 64.

9 EKLA f 350, 405: 2 (1997), p. 77.

${ }^{10}$ EKLA f 350, 405: 1 (1996), p. 2.

${ }^{11}$ EKLA f 350, 405: 1 (1996), p. 60.

12 The quoted poem by Anna Haava (1864-1957) was first published in the collection of poems Siiski on elu ilus [And yet, life is beautiful] (1930). I have assumed that the narrator found the poem from a selection of Anna Haava's poetry published in 1968 in the series Väike luuleraamat [Small book of poetry], p. 113. The poem Elus peab 
oskama imesid ihata [In life you must know how to wish for miracles] by Virve Osila (b. 1946) was published in Osila's third collection of poetry entitled Südameaed ([The garden of the heart], published in 1993), p. 6.

${ }^{13}$ She was born in November, under the astrological sign of Scorpio.

${ }^{14}$ MK: Ida-Viru County, M. T. Võóras ja oma kodu ja lähiümbruses, 2002, p. 4.

${ }^{15}$ An edited version of the life story of the narrator whose texts are analysed in this article has been published in the first volume of the anthology Eesti rahva elulood ([Estonian Life Histories], Hinrikus 2000: 159-171) and the translation of this text into English by Tiina Ann Kirss can be found in the collection She Who Remembers Survives (Kirss et al. 2004: 298-317). The edited version of the story written in Russian has been published in the anthology Rasskazhi o svoei zhizni ([Tell us your life story], Hinrikus 2005: 28-51). In order for handwritten source texts to be published, they have to be standardised. The editing process reduces the originals to homogeneous texts, therefore reducing their individuality. However, the fact that the texts are collected in a single volume brings out the similarities between the life experiences, reinforcing the impressions that readers gain from reading about individual destinies. Due to the differences between the original and the edited version of the text, the two must be kept separate when conducting research. This article is based on the original texts.

${ }^{16}$ EKLA f 350, 405: 1 (1996).

${ }^{17}$ EKLA f 350, 405: 2 (1997).

18 EKLA f 350v, 57 (2004).

${ }^{19}$ MK: Ida-Viru County, M. T. Võõras ja oma kodu ja lähiümbruses, 2002.

20 The life stories of people who were imprisoned in concentration camps have been told since 1989 and, as a rule, they do not mention the estrangement between family members in the 1950s when people returned home from imprisonment and the mandatory exile that followed it (Jaago 2007). One of the rare exceptions is the following passage: "I had been away for 12 long years and had been starving for almost the entire time. The children had grown up and did not recognise me; they only knew I was their father due to the photos I had sent them when I was in exile." (EKLA f 350, 19.) However, the quote above only contains hints at problems in the family, rather than an in-depth discussion on the subject. The emphasis of the story is on the role that political repression plays in shaping a person's life. (cf. EKLA, f 350, 4 \& 766.) On the other hand, the life stories written by the children of people who returned from Siberia address the issue of their reunions with their parents differently. The children who had been separated from their parents describe the sense of estrangement they felt when they saw their parents again (see, for example, EKLA f 350, 1369 \& 2387).

${ }^{21}$ EKLA f 350, 405: 1 (1996), pp. 6-7. The work discussed here is the book Helisev koidik [The sound of the dawn] by the Hungarian author Reneé Erdös, which was translated into Estonian and published in 1935. The protagonist of the book is a young woman who is trying to comprehend the conflict between her ideals and reality. The boyfriend of the protagonist is also a product of the young woman's imagination and does not correspond to an actual man in real life.

${ }^{22}$ The poem Võrdlus [Comparison] by Betti Alver (1906-1989) was published in 1986 in a collection of poetry entitled Korallid Emajões [Coral in the Emajõgi River]. 
${ }^{23}$ MK: Ida-Viru County, M. T. Fieldwork report, 11/12/2002.

${ }^{24}$ In addition to the narrator of the story analysed in this article, I have contacted five narrators who have submitted their stories to the Estonian Literary Museum, and in every case it appears that the text sent to the archives can be examined in connection with the other texts written by the narrator.

${ }^{25}$ In the concentration camp at Stutthof, she was "in the Jewish part of the camp. Polish and Ukrainian women ruled here. As always, the smaller peoples such as Estonians and Latvians were minorities and had no say in anything." EKLA f 350, 405: 1 (1996), p. 19.

${ }^{26}$ EKLA f 350, 405: 2 (1997), p. 53.

${ }^{27}$ EKLA f 350, 405: 2 (1997), pp. 55-56.

${ }^{28}$ MK: Ida-Viru County, M.T. Võõras ja oma kodu ja lähiümbruses, 2002, pp. 15-16.

${ }^{29}$ MK: Ida-Viru County, M.T. Võõras ja oma kodu ja lähiümbruses, 2002, p. 16.

${ }^{30}$ MK: Ida-Viru County, M.T. Võõras ja oma kodu ja lähiümbruses, 2002, p. 4.

${ }^{31}$ EKLA f 350, 405: 2 (1997), p. 57.

${ }^{32}$ EKLA f 350, 405: 1 (1996), pp. 30-31; 405: 2 (1997), p. 58.

${ }^{33}$ EKLA f 350, 405: 1 (1996), p. 2.

${ }^{34}$ EKLA f 350, 405: 2 (1997), p. 1. Estonian poetess Katre Ligi, born in 1953. The poem was published in 1988 in the collection of poetry entitled Aeg augustit ära saata [Time to send August away], p. 115.

${ }^{35}$ The song Orrn punased purjed [Red sails] was published in Tallinn in 1936 as part of volume 15 of a collection of songs entitled Modern lööklaulud [Modern hit songs], p. 13. The songs published in this series mainly included well-known pieces from films or operettas of the 1930s and, to a lesser degree, original compositions. No authors have been provided for the song in question, although the English title of the song is mentioned as Red Sails. Written recordings of this song made between 1960 and 1971 can also be found in the Estonian Folklore Archives (RKM II 43, 506; 96, 510; $168,366 ; 285,240)$. Kungla rahvas [People of Kungla], original title Vanemuine) is a song written in 1896 by Karl August Hermann (1851-1909) for a melody by Friedrich Kuhlbars (1841-1924). The song has been sung at concerts, in schools, at national song festivals and family celebrations.

\section{MANUSCRIPT SOURCES}

EKLA - Estonian Cultural History Archives of the Estonian Literary Museum

RKM - Manuscript collection of the Department of Folkloristics at the Estonian Literary Museum (1945-1996)

MK - fieldwork materials of Tiiu Jaago in possession of the author 


\section{REFERENCES}

Greverus, Ina-Maria (ed.)1988. Kulturkontakt. Kulturkonflikt. Zur Erfahrung des Fremden. Frankfurt am Main: Institut für Kulturanthropologie und Europäische Ethnologie.

Grišakova, Marina 2010. Narratiivne põhjuslikkus. [On Narrative Causality.] In: M. Grišakova (comp.) Jutustamise teooriad ja praktikad. [Narrative Theories and Practices.] Tartu: Tartu Ülikooli Kirjastus, pp. 52-67.

Hakamies, Pekka 2006. Soviet Settlers on a Strange Territory: Experiences and Narratives from the Former Finnish Karelia. In: M. Hurd (ed.) Borderland identities: Territory and Belonging in Central, North and East Europe. Eslöv: Gondolin, pp. 31-56.

Hinrikus, Rutt (ed.) 2000. Eesti rahva elulood. Sajandi sada elulugu kahes osas I. [Estonian Life Stories.] Tallinn: Tänapäev.

Hinrikus, Rutt 2003. Eesti elulugude kogu ja selle uurimise perspektiive. [The Collection of Estonian Life Histories and Perspectives of Studying It.] In: A. Krikmann \& S. Olesk (eds.) Võim ja kultuur. [Power and Culture.] Tartu: Eesti Kirjandusmuuseum, Eesti Kultuuriloo ja Folkloristika Keskus, pp. 171-213.

Hinrikus, Rutt (ed.) 2005 = Khinrikus Rutt. Rasskazhi o svoei zhizni: Zhizneopisaniia estonozemel'tsev. [Tell Me about your Life. Life Stories of Estonians.] Eesti Kirjandusmuuseum \& Ühendus Eesti Elulood. Tallinn: Aleksandra.

Hinrikus, Rutt \& Kõresaar, Ene 2004. A Brief Overview of Life History Collection and Research in Estonia. In: T. Kirss \& E. Kõresaar \& M. Lauristin (eds.) She Who Remembers Survives. Interpreting Estonian Women's Post-Soviet Life Stories. Tartu: Tartu University Press, pp. 19-34.

Jaago, Tiiu 2004a. 'It was all just as I thought and felt': One Woman's World in the Context of 20th Century Events. In: T. Kirss \& E. Kõresaar \& M. Lauristin (eds.) She Who Remembers Survives. Interpreting Estonian Women's Post-Soviet Life Stories. Tartu: Tartu University Press, pp. 144-165.

Jaago, Tiiu 2004b. Narrationen von Heimat und Abstammung. Esten und ethnische Minoritäten in Estland erzählen. In: S. Wienker-Piepho \& K. Roth (eds.) Erzählen zwischen den Kulturen. Münchener Beiträge zur Interkulturellen Kommunikation 17. Münster \& New York \& München \& Berlin: Waxmann, pp. 173-185.

Jaago, Tiiu 2007. Political Destinies: the Subject Matter of Stalinist Prison Camps in Estonian Life History Narratives (manuscript).

Jaago, Tiiu 2011. Negotiating Place Identity in Life Stories from the Viewpoint of the Multiculturalism. Ethnologia Fennica. Finnish Studies in Ethnology, Vol. 38, pp. 96-111.

Jaago, Tiiu \& Printsmann, Anu \& Palang, Hannes 2008. Kohtla-Järve: One Place, Different Stories. In: E. Näripea \& V. Sarapik \& J. Tomberg (eds.) Koht ja paik. Place and Location. Studies in Environmental Aesthetics and Semiotics VI. Tallinn: Estonian Academy of Arts, pp. 285-303.

Kirss, Tiina \& Kõresaar, Ene \& Lauristin, Marju (eds.) 2004. She Who Remembers Survives. Interpreting Estonian Women's Post-Soviet Life Stories. Tartu: Tartu University Press.

Kõresaar, Ene 2004. Memory, Time, Experience, and the Gaze of a Life Stories Researcher. In: T. Kirss \& E. Kõresaar \& M. Lauristin (eds.) She Who Remembers 
Survives. Interpreting Estonian Women's Post-Soviet Life Stories. Tartu: Tartu University Press, pp. 35-61.

Kõresaar, Ene 2005. Elu ideoloogiad. Kollektiivne mälu ja autobiograafiline minevikutõlgendus eestlaste elulugudes. Summary in English: Ideologies of Life. Collective Memory and Autobiographical Meaning-Making of the Past in Estonian PostSoviet Life Stories. Eesti Rahva Muuseumi sari 6. Tartu: Eesti Rahva Muuseum.

Laurén, Kirsi 2010. Kirjoitetun kokemuksen kiehtovuus. [The Fascination of the Written Experience.] In: J. Pöysä \& H. Järviluoma \& S. Vakimo (eds.) Vaeltavat metodit. [Travelling Methods.] Kultaneito VIII. Joensuu: Suomen Kansantietouden Tutkijain Seura, pp. 426-449.

Lotman, Juri 2005. On the Semiosphere. Sign Systems Studies, Vol. 33, No. 1, pp. 205-229, doi:10.2753/RPO1061-0405270140.

Palmenfelt, Ulf 2006. The Dark Shadow of the Un-mentioned Event. Collapsing Taleworlds and Narrative Reparation. In: A. Kaivola-Bregenhøj \& B. Klein \& U. Palmenfelt (eds.) Narrating, Doing, Experiencing. Nordic Folkloristic Perspectives. Studia Fennica: Folkloristica 16. Helsinki: Finnish Literature Society, pp. 101-116.

Pöysä, Jyrki 2006. Kilpakirjoitukset muistitietotutkimuksessa. [Collection Campaigns in Oral History Research.] In: O. Fingerroos \& R. Haanpää \& A. Heimo \& U.-M. Peltonen (eds.) Muistitietotutkimus. Metodologisia kysymyksiä. [Oral History Research: Methodological Issues.] Tietolipas 214. Helsinki: Suomen Kirjallisuuden Seura, pp. 221-244.

Rahi-Tamm, Aigi 2005. Inimkaotused. [Human Losses.] In: Ü. Ennuste \& E. Parmasto \& E. Tarvel \& P. Varju (eds.) Valge raamat. Eesti rahva kaotustest okupatsioonide läbi 1940-1991. [The White Book: Losses Inflicted on the Estonian Nation by Occupation Regimes 1940-1991.] Tallinn: Eesti Entsüklopeediakirjastus, pp. 23-42.

Schmeling, Manfred 2000. Mischung als Konzept. Ein Aspekt kultureller Grenzüberschreibung in Kulturwissenschaft und Literarischer Praxis. In: R. Marti (ed.) Grenzkultur - Mischkultur? Saarbrücken: SDV Saarbrücker Druckerei und Verlag, pp. 349-365.

Schneider, Ingo 2004. Erzählungen als kulturelle Konstruktionen. Über Bedingungen des Fremdverstehens und Grenzen des Erzählens zwischen den Kulturen. In: S. Wienker-Piepho \& K. Roth (eds.) Erzählen zwischen den Kulturen. Münchener Beiträge zur Interkulturellen Kommunikation 17. Münster \& New York \& München \& Berlin: Waxmann, pp. 21-32.

Tuisk, Astrid 2002. The Place Folklore of Siberian Estonians Today. Reflections of Adaption. In: T. Jaago \& M. Kõiva \& K. Kärsna (eds.) Lives, Histories, and Identities: Studies on Oral Histories, Life- and Family Stories. Contemporary Folklore 3. Tartu: University of Tartu \& Estonian Literary Museum, pp. 107-130.

Valge, Janek 2006. Kohtla-Järve hilis-sotsialistlik segregatsioon. Summary in English: Late Socialist Segregation of Kohtla-Järve. (Master's thesis in human geography.) Tartu: Tartu Ülikooli geograafia instituut. http://dspace.utlib.ee/dspace/bitstream/ handle/10062/1358/valge.pdf?sequence=5, last accessed on October 13, 2011.

Welzer, Harald 2000. Das Interview als Artefakt. Zur Kritik der Zeitzeugenforschung. BIOS: Zeitschrift für Biographieforschung, Oral History und Lebensverlaufsanalysen, Vol. 1, pp. 51-63.

Wienker-Piepho, Sabine \& Roth, Klaus (eds.) 2004. Erzählen zwischen den Kulturen. Münchener Beiträge zur Interkulturellen Kommunikation 17. Münster \& New York \& München \& Berlin: Waxmann. 